\title{
THE ROLE OF REACTIVE OXYGEN SPECIES IN TUMOR CELLS APOPTOSIS INDUCED BY LANDOMYCIN A
}

\author{
L. V. LEHKA $A^{1}$, R. R. PANCHUK ${ }^{1}$, W. BERGER ${ }^{2}$, Ju. ROHR ${ }^{3}$, R. S. STOIKA ${ }^{1}$ \\ ${ }^{1}$ Institute of Cell Biology, National Academy of Sciences of Ukraine, Lviv; \\ ${ }^{2}$ Institute of Cancer Research, Medical University of Vienna, Austria; \\ ${ }^{3}$ Department of Pharmaceutical Sciences, University of Kentucky, USA; \\ e-mail: lilyalehka@gmail.com
}

Landomycin A (LA) is a new antitumor antibiotic of angucycline group, possessing high antitumor activity against cancer cells of different origin, which induces early apoptosis in target cells. It was shown that under LA action the level of reactive oxygen species (ROS) in human T-leukemia cells had increased 5.6 times in comparison to control already at the $1^{\text {st }}$ hour after the addition of studied antibiotic to the culture medium. At the $6^{\text {th }}$ hour after incubation of cells with LA the nucleosomal DNA cleavage, chromatin condensation and nucleus fragmentation were observed, indicating apoptotic cell death. Catalase (scavenger of hydrogen peroxide), mannitol (scavenger of hydroxyl radicals) and superoxide dismutase (scavenger of superoxide radicals) reduced the level of $\mathrm{ROS}$ production under $\mathrm{LA}$, suggesting the generation of $\mathrm{H}_{2} \mathrm{O}_{2}, \mathrm{OH}^{\cdot}$ and $\mathrm{O}_{2}^{-}$ radicals, respectively. It was revealed that catalase and mannitol effectively inhibited LA-mediated tumor cell death, increasing 2.5 times the percentage of alive cells in comparison to LA. However, superoxide dismutase had no significant inhibitory effect on cytotoxic activity of $L A$, indicating the minor role of superoxide anions in the implementation of antitumor activity of this antibiotic. Combination of catalase, mannitol and superoxide dismutase with LA increased 4-fold the percentage of alive cells in comparison to the action of LA. Dynamics of ROS formation confirms that the increase of ROS is a very rapid process, but at the same time it is not a direct consequence of apoptosis triggering, mediated by mitochondria.

Ke y word s: landomycins, apoptosis, reactive oxygen species (ROS), malignant cells.

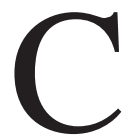

hemotherapy, targeted on the level of reactive oxygen species modulating (ROS) in tumor cells, is considered the most promising and effective strategy in the fight against cancer [1-3]. It is known that normal cells are characterized by a powerful antioxidant defense system that effectively eliminates free radicals, which are the byproducts of oxidative phosphorylation in the mitochondria. Due to this, healthy cells can tolerate high level of exogenous ROS emerging under extreme conditions. But antioxidant enzyme system of the tumor cells is unbalanced and the intensity of metabolic processes is considerably higher, resulting in a persistent oxidative stress [4]. As a consequence, above threshold ROS concentrations are not toxic to malignant cells, however, a further sudden increase in the level of free radicals in tumor cells by exognous ROS-induced agents causes their rapid death. This special feature of malignant cells makes them promising target for anticancer drugs which induce oxidative stress in tumor cells [2].
Landomycin A is a new antitumor angucycline antibiotic consisting of benzoantharacene tetracyclic aglycone and hexasaccharide chain that contains two repetitive trisaccharide subunits ( $\alpha$-L-rhodinose-(1$3)-\beta$-D-olivose-(1-4)- $\beta$-D-olivose) joined by O-glycoside bond (Fig. 1). Landomycin A possesses high cytotoxic activity toward cancer cells as well as ability to overcome acquired multidrug resistance of cancer cells to chemotherapy treatment [5]. Previous studies showed that landomycin A acts as a prooxidant, so the aim of this study was to clarify the role of ROS in apoptotic death of tumor cells induced by this antibiotic.

\section{Materials and Methods}

Landomycin A (99\% purity according to thinlayer chromatography) was obtained in the laboratory of professor Jurgen Rohr (Department of Pharmaceutical Sciences, University of Kentucky, USA).

Cells and cell culture. Jurkat cell line (human T-cell leukemia), HL-60 cell line (human acute pro- 


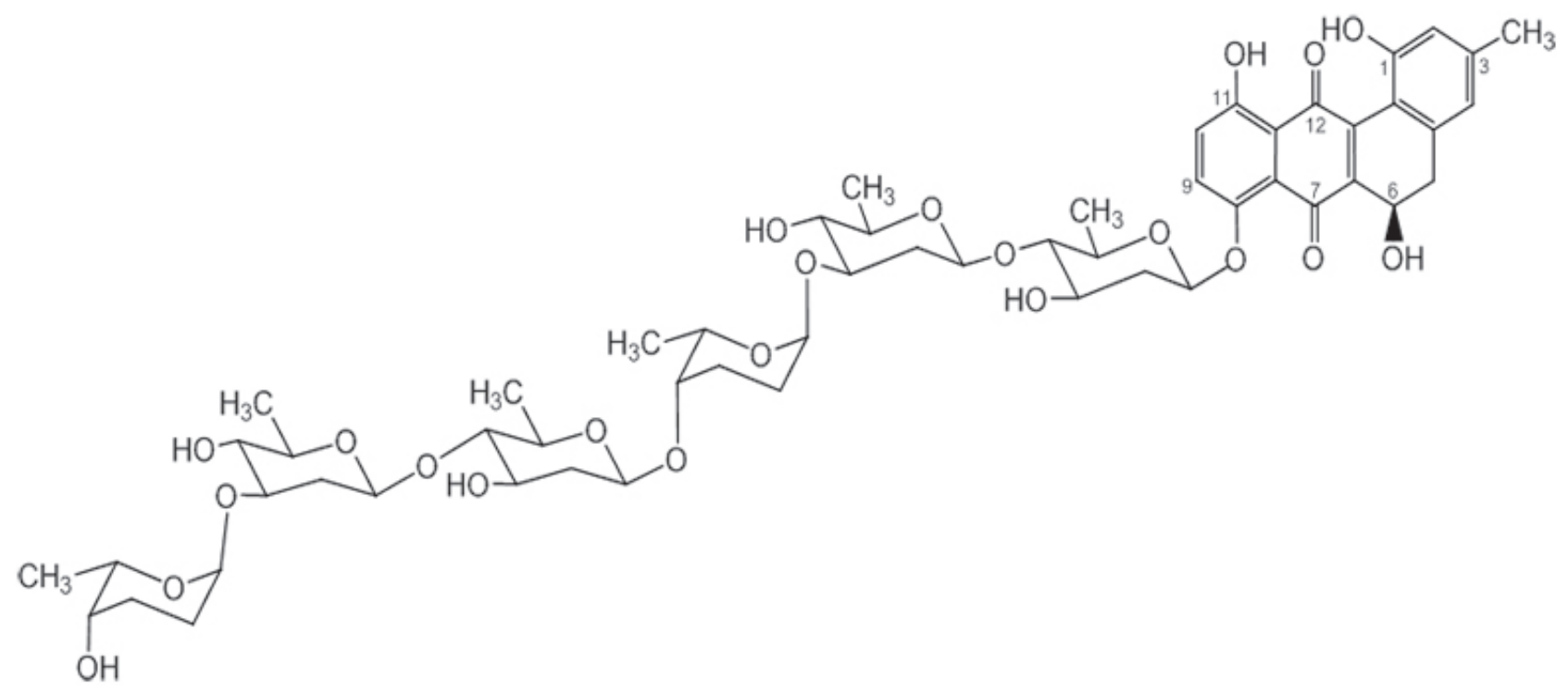

Fig. 1. Landomycin A

myelocytic leukemia) and MG-63 cell line (human osteosarcoma) were used in the study.

Cells were grown in RPMI-1640 medium (Sigma, USA) supplemented with $10 \%$ fetal bovine serum (Sigma, USA) and $50 \mu \mathrm{g} / \mathrm{ml}$ gentamicin (Sigma, USA) in $5 \% \mathrm{CO}_{2}$-containing humidified atmosphere at $37^{\circ} \mathrm{C}$. Cells were passaged every two days at the rate of $5 \times 10^{5} \mathrm{cell} / \mathrm{ml}$ of culture medium for the suspension cultures and $2.5 \times 10^{5} \mathrm{cell} / \mathrm{ml}$ of culture medium for the substrate-dependent lines [6].

Study of cytotoxic activity of LA. Cells were seeded in 24-tissue culture plates (Greiner Bio One, Germany) in culture medium at a concentration of $1 \times 10^{6} \mathrm{cell} / \mathrm{ml}$ (suspension cell) and $1 \times 10^{5} \mathrm{cell} / \mathrm{ml}$ (substrate-dependent cells). The studied compound was added to the cells at various concentrations. After $24 \mathrm{~h}$ incubation the number of cells was calculated in hemocytometer chamber by estimation of the number of dead cells using 0.1\% Trypan Blue dye. This dye stains dead cells with damaged membrane in blue, whereas alive cells remain unstained [7].

Study of DNA fragmentation using agarose gel electrophoresis. Cells were plated in Petri dishes at $1 \times 10^{6} \mathrm{cell} / \mathrm{ml}$ concentration with the addition of the studied compound in the medium. After $6 \mathrm{~h}$ incubation, cells were washed with 1-x phosphate-buffered saline (PBS) and centrifuged at $300 \mathrm{~g}$ for 6-7 min. The cell pellet was gently resuspended in a tube on ice with lysis buffer (50 mM Tris-HCl, $\mathrm{pH} 7.5$, 20 mM EDTA-Na, 1\% NP-40 detergent) at the rate of $10 \mu$ buffer per $1 \times 10^{6}$ cells. The cells were then centrifuged at $4090 \mathrm{~g}$ for 5-10 min, the supernatant was collected, and sodium dodecyl sulfate (SDS) to a final concentration of $1 \%$ and RNase A (Invitrogen, USA) to a final concentration of $5 \mathrm{mg} / \mathrm{ml}$ were added. The mixture was incubated for $2 \mathrm{~h}$ at $56{ }^{\circ} \mathrm{C}$. Thereafter proteinase K (Invitrogen, USA) was added to a final concentration of $2.5 \mathrm{mg} / \mathrm{ml}$ and incubated for $2 \mathrm{~h}$ at $37^{\circ} \mathrm{C}$. After the incubation completion, $10 \mathrm{M}$ ammonium acetate ( $1 / 2$ of volume) and chilled isopropanol (2 volumes) were added to the mixture and then centrifuged at $14000 \mathrm{~g}$ for $15-20$ min. The precipitate was washed with ethanol and re-centrifuged. Ethanol was then pipetted. The precipitate was dried at room temperature. DNA was dissolved in TBE buffer (Tris-borate-EDTA); $5 \mu \mathrm{l}$ buffer per $1 \times 10^{6}$ cells. Before the electrophoresis, a loading buffer (final concentration $7-10 \%$ sucrose) and bromophenol blue were added to samples. The samples were loaded at the rate of $1 \times 10^{6}$ cells per well. Electrophoresis was performed in 1-x TBE buffer, in $1 \%$ agarose at $35 \mathrm{~V}$ using a BioRad apparatus (Sweden).

Measurement of reactive oxygen species production. To detect ROS, the specific fluorescent dye DCFDA (2',7'-dichlorofluorescein diacetate) (Sigma, USA) was used. Before starting the experiment (i.e. addition of the studied compounds), DCFDA (final concentration $10 \mu \mathrm{M}$ ) was added to the cell medium and incubated for $30 \mathrm{~min}$. Thereafter, catalase, superoxide dismutase or mannitol (Sigma, USA) were added to final concentrations $1000 \mathrm{U} / \mathrm{ml}, 160 \mathrm{U} / \mathrm{ml}$ 
and $60 \mathrm{mM}$, respectively, and incubated for other 30 min. Next, landomycin A was added to the cells and incubated for a certain time. The fluorescence intensity was measured by flow cytometry using FACS Calibur (Becton Dickinson, Palo Alto, USA).

Double cell staining with fluorescent dyes Hoechst 33258 and propidium iodide. Cells were seeded in 6 -well plate ( $10^{5}$ cells per well). After $24 \mathrm{~h}$, the studied compounds were added and the cells were incubated for $24 \mathrm{~h}$. Thereafter, Hoechst $33258(1 \mathrm{mg} /$ $\mathrm{ml}) 1 \mu \mathrm{l} / \mathrm{ml}$ and propidium iodide $(2.5 \mathrm{mg} / \mathrm{ml}) 1 \mu \mathrm{l} /$ $\mathrm{ml}$ were added with further incubation for $1 \mathrm{~h}$. At the end of the experiment, digital images of the cells were produced using fluorescence microscope digital camera Nikon Eclipse 9000.

Measurement of mitochondrial transmembrane potential $\left(\Delta \Psi_{m}\right)$. Mitochondrial transmembrane potential $\left(\Delta \Psi_{\mathrm{m}}\right)$ was determined semi-quantitatively with JC-1 dye (5,5'-tetrachloro-1,1',3,3'-tetraethylbenzimidazolocarbocyanine iodide, Sigma, USA) using flow cytometry. Cells $\left(1 \times 10^{6}\right)$ were incubated for a certain time with the studied compound. Cells were washed with 1-x PBS and incubated for $10 \mathrm{~min}$ at $37^{\circ} \mathrm{C}$ with a freshly prepared solution of JC-1 (final concentration $10 \mu \mathrm{g} / \mathrm{ml})$. JC-1 remains were removed by washing the cells with PBS. Fluorescence intensity was evaluated by flow cytometry using FACS Calibur (Becton Dickinson, Palo Alto, USA).

Statistical data analysis. The experiments were performed in triplicate for each variant. Each point of graphs in the figures and the column ordinate on the diagram corresponds to the mean value $\mathrm{M}$, calculated on the results of the three measurements in one of several similar experiments. Standard error «m» was calculated using the mean square deviation

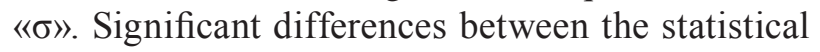
groups were determined by Student's test. The data with $P<0.05$ were considered statistically significant. The percentage of apoptotic cells (determined by the cell staining with Hoechst 33258) was counted using Image-Pro Plus 7.0 software. A computer based on AMD's with Windows 7 (Microsoft, USA) was used in the study. Statistical data processing was performed using Microsoft Excel software (Microsoft Office, 2007).

\section{Results and Discussion}

To estimate landomycin A (LA) cytotoxic activity on Jurkat cell line (human T-cell leukemia) and HL-60 cell line (human promyelocytic leukemia), Trypan Blue assay was used. The data shown in Fig. $2(A, B)$ demonstrate that the number of alive cells in both studied lines decreases depending on the duration of incubation with LA. A negative correlation between the cell number and LA concentration was observed (Fig. 2, C, D). $\mathrm{LC}_{50}$ and $\mathrm{LC}_{75}$ values (the concentrations of compounds which cause the death of $50 \%$ or $75 \%$ of the cells compared to the control) after incubation for $24 \mathrm{~h}$ were 1 and $2 \mu \mathrm{M}$ for Jurkat cells and 0.8 and $2.4 \mu \mathrm{M}$ for HL-60 cells, respectively.

For analysis of the cytomorphological features of alterations in the target cells under LA action, MG-63 human osteosarcoma cells were stained with fluorescent dye Hoechst 33258 (Fig. 3). Owing to changes in the plasma membrane permeability, apoptotic cells accumulated this dye significantly faster in comparison to intact cells. Therefore, intact cells usually have a weak fluorescence in the nucleus, whereas apoptotic cells are characterized by bright fluorescence of condensed chromatin and fragmentation of nucleus $[8,9]$. On the microscopy images we can see condensed chromatin sites (marked by red arrows) in cells treated with the studied antibiotic, indicating the induction of apoptosis, the percentage of it was about $53 \%$ for $1 \mu \mathrm{M}$ LA and $79 \%$ for $2 \mu \mathrm{M}$ LA.

Internucleosomal DNA fragmentation is considered as one of the most important biochemical features of apoptosis $[10,11]$. To detect the DNA fragmentation in tumor cells of HL-60 line after exposure to LA, agarose gel electrophoresis was performed. Already at the 6th hour after incubation the cells with $1 \mu \mathrm{M}$ of LA the DNA-ladder could be observed confirming the cell death by apoptosis (Fig. 4).

It is known that many anticancer drugs used in chemotherapy cause oxidative stress as a result of ROS induction [12]. For studying the ROS generation in cells under LA action, a non-fluorescent dye dihydrochlorofluorescein diacetate $\left(\mathrm{H}_{2}\right.$ DCFDA) which possesses the affinity to $\mathrm{H}_{2} \mathrm{O}_{2}$ was used. $\mathrm{H}_{2}$ DCFDA diffuses through the cell membrane and then is deacetylated to $\mathrm{H}_{2}$ DCF by intracellular esterases in the presence of ROS. $\mathrm{H}_{2} \mathrm{DCF}$, in turn, is oxidized and converted into $2^{\prime}, 7^{\prime}$ - - dichlorofluorescein (DCF), which is able to fluoresce. It was shown that LA caused early generation of ROS in Jurkat cells (Fig. 5). At the first hour after LA addition in $1 \mu \mathrm{M}\left(\mathrm{LC}_{50}\right)$ concentration the level of ROS statistically significant $(P<0.01)$ increases 5.6 -fold in comparison to control. With the increasing of incubation 

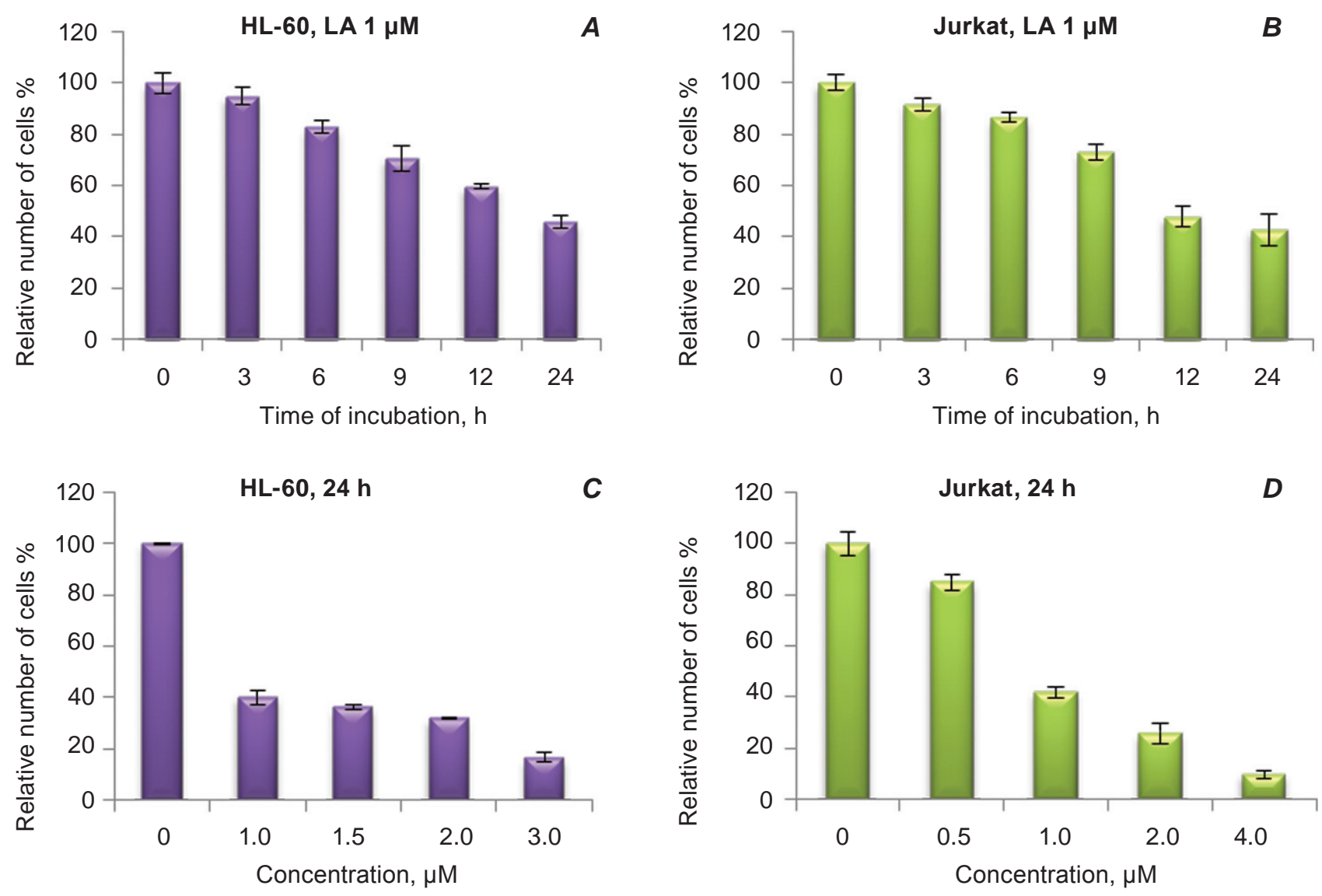

Fig. 2. Cytotoxic effect of landomycin A (LA) on Jurkat cell line (human T-cell leukemia) and HL-60 line (human promyelocytic leukemia) (see the text for explanations)

duration with studied antibiotic the level of ROS decreased but it still remained higher than in control.

ROS are oxygen-containing reactive molecules including $\mathrm{O}_{2}^{-}, \mathrm{H}_{2} \mathrm{O}_{2}$ and $\mathrm{OH}^{*}$ radicals. In our work a series of ROS scavengers such as superoxide dismutase, catalase and mannitol was used to study their influence on ROS production in tumor cells under landomycin A action (Fig. 6). It was found that catalase already at early time points $(1,3 \mathrm{~h})$ significantly reduced ROS level (almost 3.5 fold in comparison to the amount of ROS produced under LA action). This indicates an increase in the generation of hydrogen peroxide in the presence of studied antibiotic. Mannitol and superoxide dismutase also decreased the level of ROS, but to much less extent (2- and 1.3-fold, respectively). It confirmes the generation of $\mathrm{OH}^{-}$and $\mathrm{O}_{2}^{-}$radicals under $\mathrm{LA}$ action. The similar tendency was observed at late time points (6, 12, $24 \mathrm{~h}$ ) after LA addition to the culture medium, however the inhibitory effect of ROS scavengers, produced in the presence of LA, was significantly lower compared to values obtained at early time points.

It is known that the antitumor activity of most anticancer drugs used in chemotherapy (alkylating factors, plant alkaloids, antimetabolites, taxanes, platinum compounds, camptothecin, etoposide, anthracyclines etc.) is achieved, among other things, through the generation of ROS. Free radicals formed during the oxidative stress influence on different cellular targets, causing cell cycle arrest, damage of DNA, lipids, proteins and cell membranes. Lipid peroxidation in mitochondrial membrane leads to membrane permeability, which causes disorder of the electron transport chain, release of cytochrome $c$ into cytosol, activating processes of programmed cell death [13-15].

To determine whether ROS are involved in Jurkat cells death induced by landomycin A, Trypan Blue assay was used. Mannitol, superoxide dismutase and catalase were used to inhibit the production of ROS in the presence of studied antibiotic. 


\section{Differential-interference contrast}
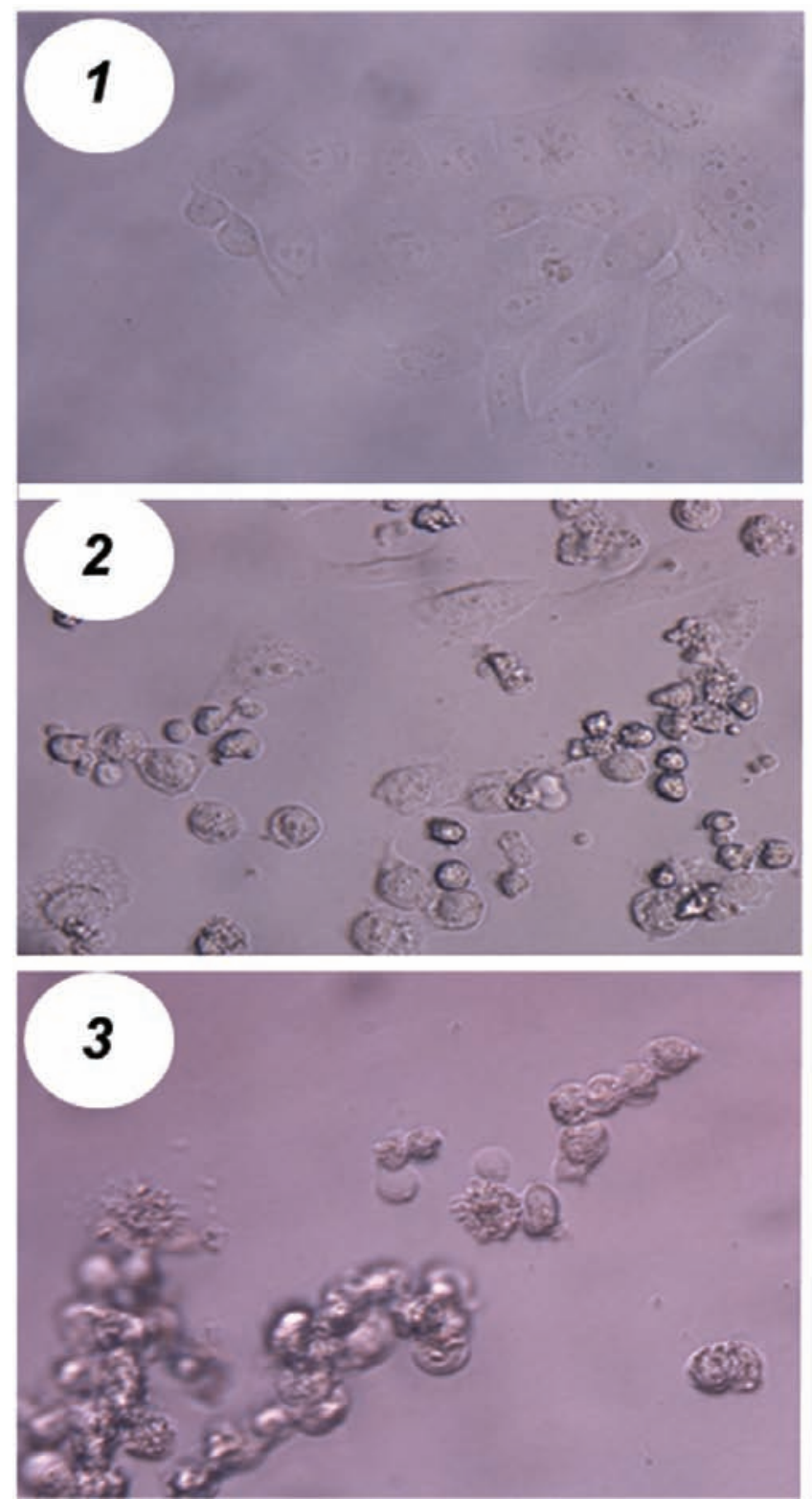

Hoechst 33258
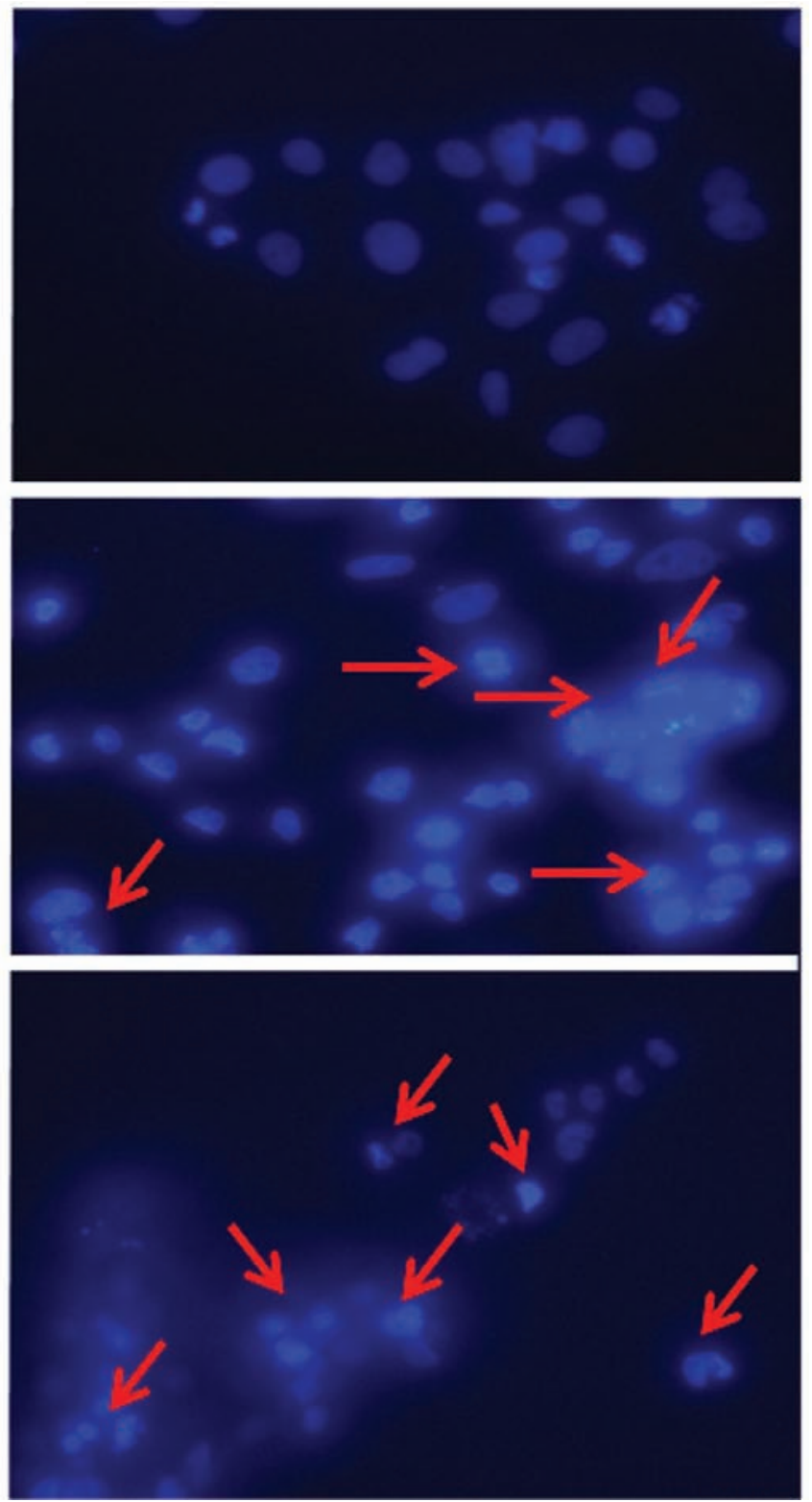

Fig. 3. Cytomorphological analysis of the chromatin state in human osteosarcoma MG-63 cells (staining with Hoechst 33258, 24 h): 1 - control; 2 - landomycin A (1 $\mu$ M); 3 - landomycin A (2 $\mu M) . \longrightarrow$ The arrows point to condensed chromatin regions

It was found that catalase (scavenger of $\mathrm{H}_{2} \mathrm{O}_{2}$ ) and mannitol (scavenger of hydroxyl radicals) effectively inhibited LA-induced cell death, increasing 2.5-fold the percentage of alive cells in comparison to studied antibiotic (Fig. 7). SOD did not exhibit significant inhibitory effect on the cytotoxic activity of LA that indicates a minor role of superoxide anions (compared to hydrogen peroxide and hydroxyl radicals) in the implementation of antitumor activity of this antibiotic. The combined use of catalase, superoxide dismutase and mannitol had the highest inhibitory effect on the cytotoxic effect of LA, and the percentage of the alive cells increased by almost 4-fold compared to the effect of studied antibiotic.

To evaluate the cytoprotective effect of mannitol and catalase on LA cytotoxic activity, double staining of MG-63 human osteosarcoma cell line using Hoechst 33258 and propidium iodide (PI) fluorescent dyes was performed. As it is seen on the images (Fig. 8), the cells treated with $1 \mu \mathrm{M} \mathrm{LA}$ are 


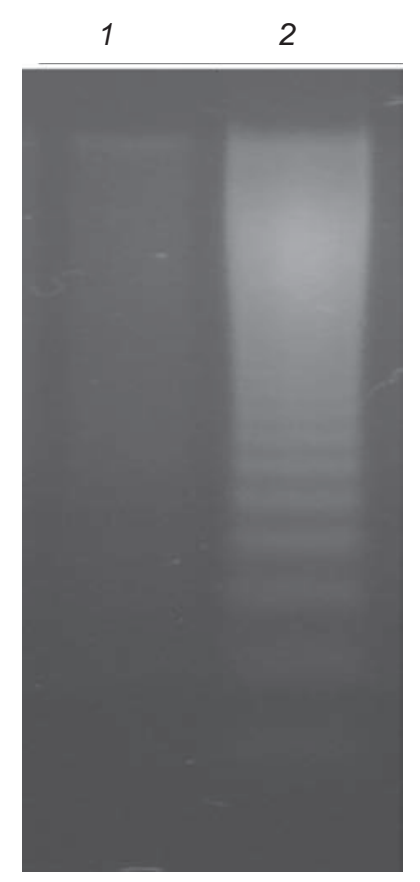

Fig. 4. DNA fragmentation in the cells of HL-60 line (human acute promyelocytic leukemia) under landomycin A action, 6 h: 1 - control; 2 - landomy$\operatorname{cin} A, 1 \mu M$

characterized by intensive condensation and fragmentation of nuclear chromatin that indicates apoptosis in these cells. Preliminary incubation of cells with mannitol (before the addition of LA) led to a partial decrease of the above-mentioned changes in the nuclear chromatin structure that confirms the involvement of hydroxyl radicals in the process of cell death in the presence of this antibiotic. In turn, the addition of catalase to the culture medium almost completely eliminated the chromatin condensation induced by LA. The obtained data agreed with the results of the cytotoxic activity of studied antibiotic as well as the results of analysis of ROS modulators influence on free radical level in tumor cells in the presence of LA. It was found that catalase possessed the highest inhibitory effect on anti-tumor activity as well as ROS production by tumor cells under studied compound. These results indicate that ROS, in particular hydrogen peroxide, hydroxyl and partly superoxide radicals are mediators of cell death and involved in LA-induced apoptosis.

The decreasing of mitochondrial membrane potential (MMP) is one of the earliest apoptosis markers [15]. To find the connection between the inducing of cell death and oxidative stress in tumor cells under LA action, Jurkat cells were stained with a fluorescent dye JC-1. At normal mitochondrial transmembrane potential, the dye enters the organelles, accumulates there and forms J-aggregates, which fluoresce in the red spectrum. As MMP decreases, JC-1 cannot accumulate in organelles and remains in the cytoplasm in monomeric form, emitting green fluorescence that can be detected by flow cytometry [16]. It was observed that after $6^{\text {th }} \mathrm{h}$ of cells incubation with LA the percentage of depolarized mitochondria statistically significant $(P<0.05)$ increased and was $22 \%$ with further increasing (Fig. 9). Thus, the apoptosis-associated alterations in mitochondria were observed at the 6th hour after LA addition to the culture medium.

Antitumor agents, widely used in chemotherapy, which induce high level of ROS in cancer cells, include platinum compounds (cisplatin, oxyplatin), etoposide, camptothecins (topotecan) as well as anthracyclines (doxorubicin, epirubicin) [17, 18]. It was established that most of these anticancer drugs may affect the mitochondria, causing the elevation of $\mathrm{O}_{2}{ }^{-}$radical level, due to either blocking the electron transport chain or capacity to accept electrons from NADPH-dependent dehydrogenases and transfer them to molecular oxygen with no inhibitory effect on the respiratory chain. Thereafter a superoxide radical can undergo spontaneous or enzymatic dismutations to form hydrogen peroxide, which in turn is able to transform in a hydroxyl radical [15, 17, 19, 20]. Our results suggest that a key role in antitumor activity of studied antibiotic rather belongs to hydrogen peroxide than to superoxide-radicals. Dynamics of ROS production in cancer cells in the presence of LA illustrates that the elevation of $\mathrm{H}_{2} \mathrm{O}_{2}$ level is a very fast process (the first hour after LA addition to the culture medium) however it is not a direct consequence of mitochondria damage or electron transport chain blocking. This distinguishes the mechanisms of ROS generation in tumor cells under studied antibiotic from the effect of above-mentioned anticancer drugs. Further investigations of ROS generation mechanism and molecular targets of landomycin A are in progress.

Literature data indicate that many types of tumor cells are characterized by a high basal ROS level (such as melanoma, breast cancer, ovarian carcinoma, prostate cancer, leukemia etc.) and sensitivity to the action of pro-oxidants [21]. Summarizing the reported results of the studies on ROS-generation induced by landomycin $\mathrm{A}$, we can suggest that this antibiotic is a promising chemotherapeutic agent. 


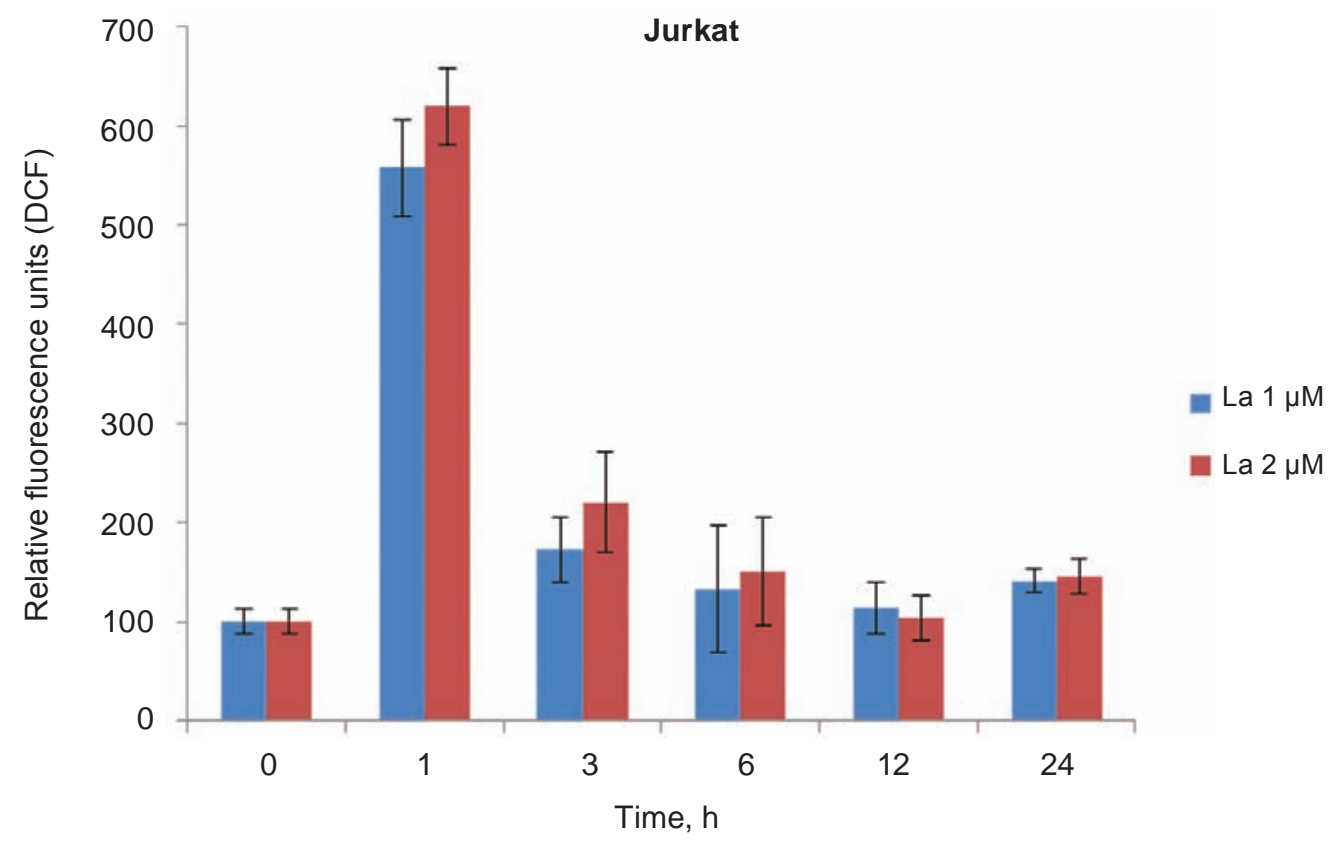

Fig. 5. Influence of landomycin A (LA) on ROS production in human T-leukemia cells of Jurkat line

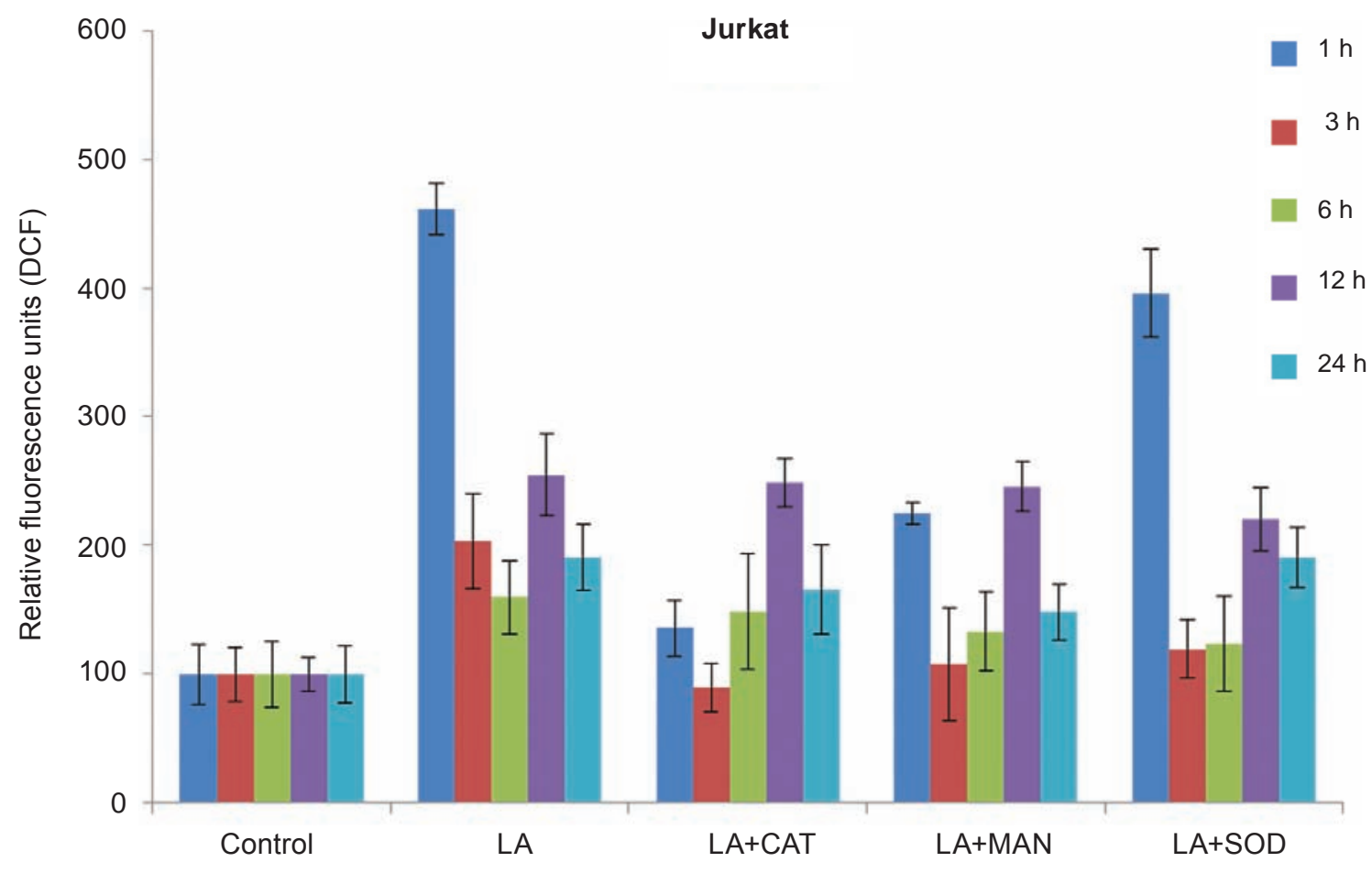

Fig. 6. Effect of catalase (CAT), mannitol (MAN) and superoxide dismutase (SOD) on ROS production of human T-leukemia cells of Jurkat line under the action of landomycin A (LA), $1 \mu M$

Thus, we have shown that landomycin A possesses significant anti-tumor activity against leukemia and carcinoma cells and induces early apoptosis in target cells. Thus, already at the $6^{\text {th }} \mathrm{h}$ after cells incubation with studied antibiotic it the internucleoso- mal DNA cleavage (DNA-ladder) was observed that together with nuclear fragmentation and chromatin condensation indicate tumor cell death by apoptosis. The experiments with catalase, superoxide dismutase and mannitol have confirmed the important 


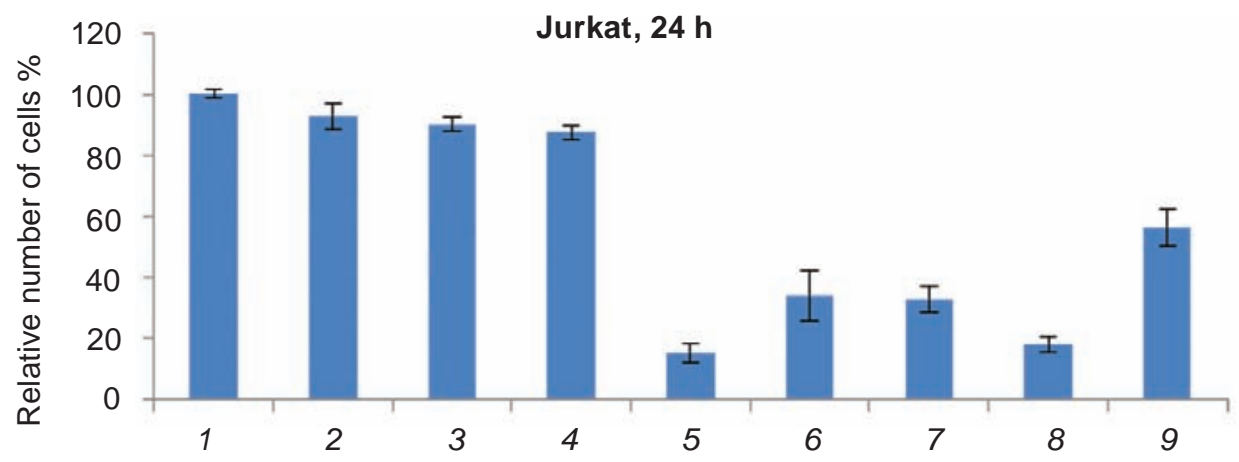

Fig. 7. Inhibitory effect of ROS-scavengers on the induction of cell death under the action of landomycin A, $1 \mu M$ : 1 - control (C); $2-C+C A T ; 3-C+M A N ; 4-C+S O D$; $5-L A ; 6-L A+C A T ; 7-L A+M A N$; 8-LA+SOD; $9-L A+C A T+M A N+S O D$

Hoechst 33258
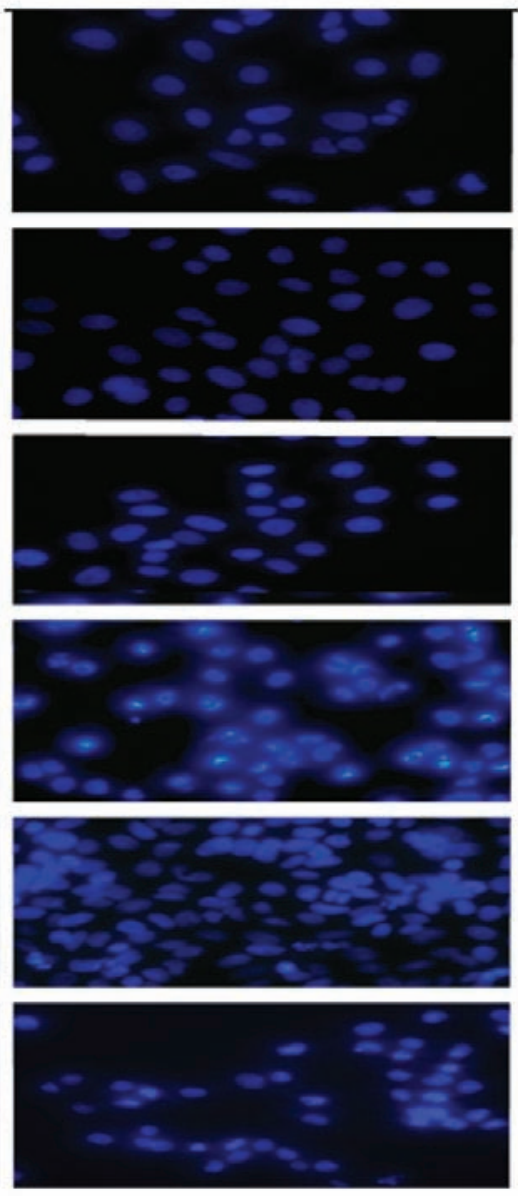

PI
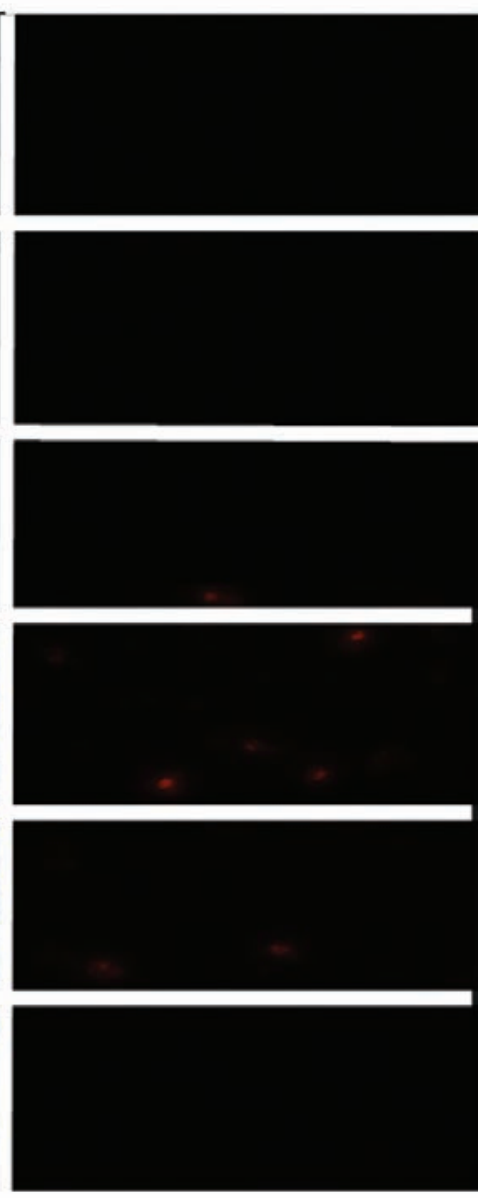

Fig. 8. Cytomorphological analysis of chromatin state in human osteosarcoma MG-63 cells after incubation with landomycin A (1 $\mu \mathrm{M})$, catalase (CAT) or mannitol (MAN), $24 \mathrm{~h}$

role of ROS, especially $\mathrm{H}_{2} \mathrm{O}_{2}$, in this process. It has been shown that the ROS generation by tumor cells in the presence of LA is a very rapid process, but is not a consequence of apoptosis triggering, mediated by mitochondria.
Acknowledgements. This work was partially supported by grants given to L. Lehka by WestUkrainian BioMedical Research Centre (UkraineUSA) in 2013-2014 and Ukrainian-Austrian bilateral collaboration project № M/112-2014. 


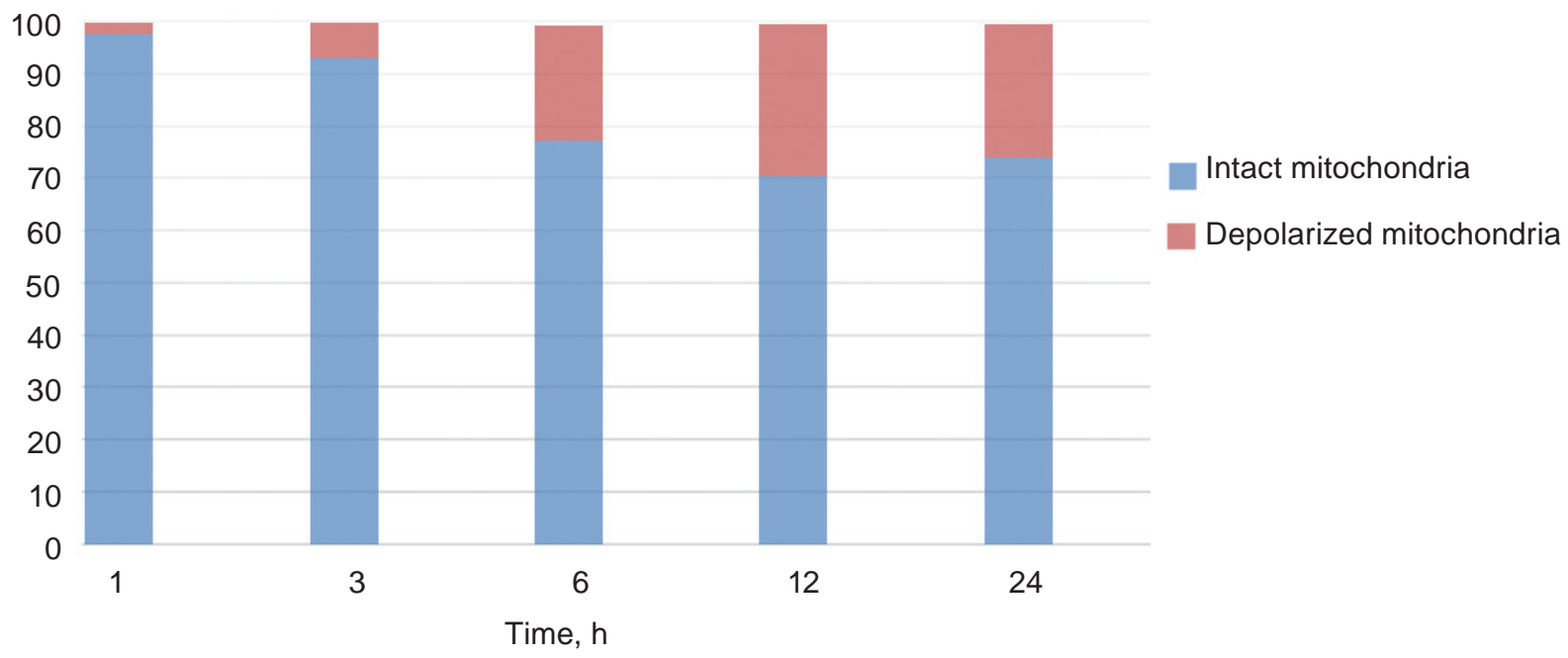

Fig. 9. Influence of landomycin $A(1 \mu M)$ on the level of mitochondrial transmembrane potential in human Jurkat T-leukemia cells

\section{РОЛЬ АКТИВНИХ ФОРМ КИСНЮ В АПОПТОЗІ ПУХЛИННИХ КЛІТИН, ІНДУКОВАНОМУ ЛАНДОМІЦИНОМ А}

\author{
Л. В. Легка ${ }^{1}$ Р. Р. Панчук , В. Бергер², \\ Ю. Рор ${ }^{3}$, Р. С. Стойка
}

${ }^{1}$ Інститут біології клітини НАН України, Львів;

${ }^{2}$ Інститут ракових досліджень, Медичний університет Відня, Австрія;

${ }^{3}$ Університет Кентуккі, відділ фармацевтичних наук, США; e-mail: lilyalehka@gmail.com

Ландоміцин А (ЛА) - новий протипухлинний антибіотик ангуциклінового ряду, який виявляє виражену протипухлинну активність щодо ракових клітин різного походження та індукує ранній апоптоз у клітинах-мішенях. Показано, що рівень активних форм кисню (АФК) у клітинах лінії Jurkat Т-лейкозу людини зростав у 5,6 раза порівняно 3 контролем уже на 1-шу годину після додавання ЛА в культуральне середовище. На 6-ту годину інкубації клітин із ЛА спостерігали міжнуклеосомне розщеплення ДНК, що разом із конденсацією хроматину та фрагментацією ядра вказувало на апоптичну загибель клітин. Каталаза (скевенджер пероксиду водню), манітол (скевенджер гідроксилрадикалів) і супероксиддисмутаза (скевенджер супероксидних радикалів) знижували рівень продукції АФК під впливом ЛА, вказуючи на генерацію $\mathrm{H}_{2} \mathrm{O}_{2}, \mathrm{OH}^{*}$ і $\mathrm{O}_{2}^{-}$радикалів відповідно. Встановлено, що каталаза та манітол ефективно пригнічували ЛА-опосередковану загибель пухлинних клітин і збільшували в 2,5 раза відсоток живих клітин порівняно з ЛА. Проте супероксиддисмутаза не виявляла значного інгібувального ефекту на цитотоксичну активність ЛА, що свідчить про мінорну роль супероксид-аніонів у реалізації протипухлинної дії останнього. Використання каталази, манітолу і супероксиддисмутази разом із ЛА збільшувало відсоток живих клітин у 4 рази порівняно з дією досліджуваного антибіотика. Результати утворення АФК підтверджують, що збільшення їхньої кількості є дуже швидким процесом, але, разом з тим, не $€$ прямим наслідком запуску апоптозу, опосередкованого мітохондріями.

К л ю ч о в і с л о в а: ландоміцини, апоптоз, активні форми кисню, злоякісні клітини. 


\section{РОЛЬ АКТИВНЫХ ФОРМ КИСЛОРОДА В АПОПТОЗЕ ОПУХОЛЕВЫХ КЛЕТОК, ИНДУЦИРОВАННОМ ЛАНДОМИЦИНОМ А}

\author{
Л. В. Легка ${ }^{1}$, Г. Г. Панчук ${ }^{1}$ В. Бергер², \\ Ю. Рор ${ }^{3}$, Р. С. Стойка
}

${ }^{1}$ Институт биологии клетки НАН Украины, Львов;

${ }^{2}$ Институт раковых исследований,

Медицинский университет Вены, Австрия;

${ }^{3}$ Университет Кентукки, отдел

фармацевтических наук, США; e-mail: lilyalehka@gmail.com

Ландомицин А (ЛА) - новый противоопухолевый антибиотик ангуциклинового ряда с выраженной противоопухолевой активностью в отношении раковых клеток различного происхождения и способностью вызывать ранний апоптоз в клетках-мишенях. Показано, что уровень активных форм кислорода (АФК) в клетках линии Jurkat T-лейкоза человека повышался в 5,6 раза по сравнению с контролем уже в течение 1-го часа после добавления ЛА в культуральную среду. На 6-й час инкубации клеток с ЛА наблюдалось межнуклеосомное расщепление ДНК, что вместе с конденсацией хроматина и фрагментацией ядра указывало на апоптическую гибель клеток. Каталаза (скэвенджер пероксида водорода), маннитол (скэвенджер гидроксил-радикалов) и супероксиддисмутаза (скэвенджер супероксидных радикалов) снижали уровень продукции АФК под влиянием ЛА, указывая на генерацию $\mathrm{H}_{2} \mathrm{O}_{2}, \mathrm{OH}^{-}$и $\mathrm{O}_{2}^{-}$радикалов соответственно. Установлено, что каталаза и маннитол эффективно подавляли ЛА-опосредованную гибель опухолевых клеток, увеличивая в 2,5 раза процент живых клеток по сравнению с действием ЛА. Однако супероксиддисмутаза не вызвала значительного ингибирующего эффекта на цитотоксическую активность ЛА, что свидетельствует о минорной роли супероксид-анионов в реализации противоопухолевого действия последнего. Использование каталазы, маннитола и супероксиддисмутазы в сочетании с ЛА увеличивало процент живых клеток в 4 раза по сравнению с действием исследуемого антибиотика. Результаты образования АФК подтверждают, что увеличение их количества является очень быстрым процессом, но, вместе с тем, не являет- ся прямым следствием запуска апоптоза, опосредованного митохондриями.

Кл ю ч в в е с лов а: ландомицины, апоптоз, активные формы кислорода, злокачественные клетки.

\section{References}

1. Kong Q., Beel J. A., Lillehei K. O. A threshold concept for cancer therapy. Med. Hypotheses. 2000;55(1):29-35.

2. Trachootham D., Alexandre J., Huang P. Targeting cancer cells by ROS-mediated mechanisms: a radical therapeutic approach? Nat. Rev. Drug Discov. 2009;8(7):579-591.

3. Gorrini C., Harris I. S., Mak T. W. Modulation of oxidative stress as an anticancer strategy. Nat. Rev. Drug Discov. 2013;12(12):931-947.

4. Manuel M., Mario D. C. Oxidative Stress and Diseases. InTech, 2012. 519 p.

5. Ostash B., Korynevska A., Stoika R., Fedorenko V. Chemistry and biology of landomycins, an expanding family of polyketide natural products. Mini Rev Med Chem. 2009;9(9):1040-51.

6. Adams R., Laboratory techniques in biochemistry and molecular biology. Elsevier. 1990. P. 16-94.

7. Freshney R. I. Culture of animal cells: a manual of basic technique and specialized applications, $6^{\text {th }}$ edition. Wiley-Backwell, 2010. $768 \mathrm{p}$.

8. Ziegler U., Groscurth P. Morphological Features of Cell Death. News Physiol. Sci. 2004;(19):124128.

9. Saraste A., Pulkki K. Morphologic and biochemical hallmarks of apoptosis. Cardiovasc. Res. 2000;45(3):528-37.

10. Nagata S. Apoptotic DNA Fragmentation. Exp. Cell Res. 2000;256(1):12-18.

11. Matassov D., Kagan T., Leblanc J., Sikorska M., Zakeri Z. Measurement of apoptosis by DNA fragmentation. Methods Mol. Biol. 2004;282:117.

12. Noriko N., Wakasugi H. Cancer and Oxidative Stress. J. Japan Med. Assoc. 2000;124(11):15711574.

13. Manda G., Nechifor M., Neagu T-M. Reactive Oxygen Species, Cancer and Anti-Cancer Therapies. Curr. Chem. Biol. 2009;3(1):22-46.

14. Conklin K. A. Cancer chemotherapy and antioxidants. J Nutr. 2004;134(11):3201S-3204S. 
15. Deavall D. G., Martin E. A., Horner J. M., Roberts R. Drug-induced oxidative stress and toxicity. J. Toxicol. 2012;2012:645460.

16. Nuydens R., Novalbos J., Dispersyn G., Weber C., Borgers M., Geerts H. A rapid method for the evaluation of compounds with mitochondriaprotective properties. J. Neurosci. Methods. 1999 Oct 15;92(1-2):153-9.

17. Conklin K. A. Chemotherapy-associated oxidative stress: impact on chemotherapeutic effectiveness. Integr. Cancer Ther. 2004;3(4):294-300.

18. Angsutararux P., Luanpitpong S., Issaragrisil S. Chemotherapy-Induced Cardiotoxicity: Overview of the Roles of Oxidative Stress. Oxidative Medicine and Cellular Longevity. 2015. P. 1-13.
19. Minotti G., Menna P., Salvatorelly E., Cairo G., Gianti L. Anthracyclines: Molecular Advances and Pharmacologic Developments in Antitumor Activity and Cardiotoxicity. Pharmacol. Rev. 2004;56(2):185-229.

20. Turrens J. F. Mitochondrial formation of reactive oxygen species. J. Physiol. 2003;552(Pt 2):335344.

21. Kirshner J. R., He S., Balasubramanyam V., Kepros J., Yang C. Y., Zhang M., Du Z., Barsoum J., Bertin J. Elesclomol induces cancer cell apoptosis through oxidative stress. Mol Cancer Ther. 2008;7(8):2319-2327.

Received 22.05.2015 